\title{
Impact of Behavioral Factors in Making Investment Decisions and Performance: Study on Investors of National Stock Exchange
}

\author{
Sarika Keswani ${ }^{1}$, Vippa Dhingra ${ }^{2} \&$ Bharti Wadhwa $^{3}$ \\ ${ }^{1}$ Research Scholar, Symbosis International University, Pune, India \\ ${ }^{2}$ Assistant Professor, Amity Business School, Amity University Gwalior, MP., India \\ 3 Associate Professor, Symbiosis Centre for Management Studies, Noida, Symbiosis International University, \\ Pune, India \\ Correspondence: Sarika Keswani, Research Scholar, Symbosis International University, Pune, India. E-mail: \\ sarika.keswani83@gmail.com
}

Received: May 14, 2019

Accepted: June 19, 2019

Online Published: July 10, 2019

doi:10.5539/ijef.v11n8p80

URL: https://doi.org/10.5539/ijef.v11n8p80

\begin{abstract}
Market anomalies and irrational behavior caused investors changes in the stock market, and this has led to an investigation into the impact of various behavioral biases and factors affecting decision-making for individual investors. The purpose of this study was to find out the effect of the four factors, heuristic, prospect, market, herding on decisions of investors at NSE. Data are collected from the questionnaire on the basis of a likert scale. To determine the reliability of the questionnaire, the Cronbach alpha factor, which was 0.728 , was used. EFA and multiple regression tests have been applied. Cronbach-alpha was used to check the interal consistency of the element. Cronbach alpha emphasized to each factor: Heuristic, Prospect, Market, Herding, Investment performance and Investors decisions that consistency at an acceptable level. The result of the analysis is that the four variables have greatly influenced the investment decision and return on investment. All behavioral variables have a significant impact on the decision-making process of investors, which led to the acceptance of all assumptions regarding the level of influence of behavioral factors in decision making for individual investors.
\end{abstract}

Keywords: heuristic, prospect, market, herding, investment performance and investors' decision

\section{Introduction}

\subsection{Introduction to Problem}

The stock market trends are determined by the investor's decision. Traditional finance has been used in the past year to understand how investors make their investment decisions. Most traditional financial theories consider investors as rational decision makers. This means that when an investor receives information, the investment decision is taken according to beliefs and updated information. In recent decades, it has been the concept of behavioral finance that combined psychological and sociological theories with finance. Behavioral finance was first considered by psychologist Daniel Kahneman and economist Vernon Smith, who received the Nobel Prize for Economics in 2002. In this context, psychologist Daniel Kahneman and Amos Tversky contributed to the field of psychology and finance and characterized the new field as behavior finance in the 1980s and this field is basically about how different people act in the financial markets or in financial environments. Basically, financing is based on how financial decisions of individuals and companies are affected by psychology in financial environments (Nofsinger, 2001).

This was the moment when the economy began to believe that investors were sometimes irrational and that their decisions might be biased due to the inability to process complex information and the lack of mental abilities. Therefore, your investment decisions are sometimes based on shortcuts of information processing and emotional files.

Understanding investors' decision making needs to study the behavioral factors that influence the decision of the investors of the National Stock Exchange. The paper attempts to study the behavioral factors (heuristics, prospects, market and herding) in the investment decision of the investors, which may even lead to the return of the investment. 
"Behavior of investor is a part of behavior finance, which seeks to understand and predict systematic financial market implications of psychological decision processes. Behavior finance closely combines individual behavior and market phenomena and uses knowledge taken from both the psychological field and financial theory." (Fromlet, 2001).

\subsection{Heuristic Theory}

In fact, heuristic methods are a golden rule and short spiritual clues that lead to greater comfort in the decision-making process, especially in complex and uncertain environments (Kahneman \& Tversky, 1979). Kahneman and Tversky (1979) are the first authors to introduce factors heuristic methods into three sets including representativeness bias availability and anchor (Kahneman \& Tversky, 1979). Waweru et al. (2008) added two factors to the heuristic factors that included the player's deception and belief.

\section{Representation}

It is a tendency of investors to make investment decisions, assuming that recent events will continue in the future and ignore their long-term impact. They also buy some shares based on a few sample stocks, those with the highest sales. The representation refers to the degree of similarity that an event has with its older population (DeBondt \& Thaler, 1995) or the extent to which the population appears (Kahneman \& Tversky, 1979). Representation can lead to a certain prejudice, if people are overweight in recent experience and ignore the long-term average rate (Ritter, 2003).

Overconfidence is that investors overestimate their knowledge based on their positive market experience. In such a case, the investor underestimates the risk and his excessive optimism leads him to invest with little diversification. When people overestimate the reliability of their knowledge and skills, it is the manifestation of overconfidence (DeBondt \& Thaler, 1995, p. 389; Hvide, 2002).

Anchoring refers to investors who use historical trends to define the size of stock prices and make investment decisions. The anchor is a phenomenon used in the situation where people use it to estimate some initial values, which are preferred for the initial, since the different starting points produced different estimates (Kahneman \& Tversky, 1979).

Gambler's fallacy is the perception of investors that the trend will return to the market in a positive way. This prejudice arises in the stock market when the investor mistakes the inverse points and is considered the end of good or bad results. Investors are trying to predict the conversion into stocks when they suffer from this bias, believing that this trend will return (Waweru et al., 2008).

Availability bias is based on the information available to investors. They make their investment decisions based on the information they have and therefore invest in family companies in a less diversified way.

\subsection{Prospect Theory}

It describes the decision-making process of the investor. The investor can regret his decision which can lead to the loss. The levels of mental stress caused by loss or profit are the aversion to loss and the investor's evaluation of their financial transaction prepares them to invest or avoid investments, which are called their spiritual accounting. According to Huang (2001), there are two forms of spiritual accounting that include loss-making and a narrower framework in two asset valuation frameworks, one for the individual shares and the other for the portfolio. The individual inventory framework was more successful. This enables an investor to organize his portfolio, which can lead to better performance and thus improve return on investment.

\subsection{Market Theory}

Investor decisions are influenced by changes in market prices, stock preferences, changes in consumer reactions, etc. This can lead an investor to respond to the market situation insufficiently or excessively. Changes in fundamental values, the market price, market information can lead to the reaction of an investor and his decisions to invest in the market. Investors can mistakenly observe that market information can affect their decisions in the market and this over-reaction can in turn lead to significant stock market changes. Past trends in equities should not motivate the investor to respond to expectations and past experience. The market-related factors are not behavioral factors, but affect investor behavior and can lead to significant changes in investor decision-making.

\subsection{Herding Effect}

It's the tendency of investors to follow the reactions of others. Grazing is considered an important factor, as it greatly influences the risk characteristics and performance values (Tan, Chiang, Mason, \& Nelling, 2008). The heritage can greatly contribute to the analysis and performance evaluation because individuals with poor ability 
try to imitate individuals' behaviors that have a great ability to develop their reputation (Kallinterakis, Munir, \& Markovic, 2010), the decisions of buying and selling other investors depend on the decisions of other investors as this leads to a decrease risk The efficient market is due to the fact that rational investors do not follow the masses, rating leads to speculative conditions that make the market ineffective.

Perceived risk: the risk capacity of investors varies from person to person. A subjective construct influenced by how the event is interpreted (Tversky \& Koehler, 1994; Weber, 2004). Investors' perception of risk is influenced by the amount of information available to them. Incomplete information can lead to greater risk and in turn can cause a loss. The tendency to risk is a common risk-taking behavior. Weber et al. (2002) has a scale of risk appetite specific domain, including the financial domain, which differentiates domain between investment and gambling. They found that perception of benefits and risks, and keeping no danger, are related to gender differences and risk-taking domination.

\subsection{Objective of the Study}

1) To identify the behavioral variables influencing individual investment decision makers at the NSE.

2) To know the impact levels (if any) of the behavioral factors influence the individual investment decisions at the NSE.

3) To know the impact of the individual investment decisions on the investment performance of investors at the NSE.

\section{Research Methodology}

The study population consisted of individual NSE investors. A cross-sectional design was used in this study. The study conforms to the nature of this study to describe the general trend of investor behavior rather than a specific case and the data from this study were not compiled in phases, but were performed in a single period. The data collected from the questionnaires provide the basic concepts of the factors that influence investor decisions. The application documents were sent to 361 respondents using stratified random sampling.

\subsection{Design of Measurements and Questionnaire}

To measure the data, we used a questionnaire divided into 3 parts: personal information, behavioral factors that influence investment decisions and the impact on return on investment. The 5-point Likert scales were used to assess the degrees of investor's decision agreement with the impact of behavioral factors in the investment decision, as well as the return on investment. The 5 points on the scale are respectively from 1 to 5: strongly disagree, disagree, neutral, agree and strongly agree.

Behavioral factors influencing the investors' decision-making are divided into four groups: heuristic, prospect, market, and herding effect, which are presented in the Table 1, Table 2 and Table 3.

Table 1. Variable description

\begin{tabular}{ll}
\hline Theory & Behavioral variables \\
\hline Heuristic Theory & - Representativeness \\
& - Overconfidence \\
& - Anchoring \\
& - Gambler's fallacy \\
& - Availability bias \\
\hline Prospect Theory & - Loss aversion \\
& - Regret aversion \\
& - Mental accounting \\
\hline Market & - Price changes \\
& - Market information \\
& - Past trends of stocks \\
& - Fundamentals of underlying stocks \\
& - Customer preference \\
& - Over-reaction to price changes \\
\hline Herding Effect & - Buying and Selling decisions of other investors \\
& - Choice of stock to trade of other investors \\
& - Volume of stock to trade of other investors \\
& - Speed of herding \\
\hline
\end{tabular}


Table 2. Variable description

\begin{tabular}{ll}
\hline Investment Decisions & I feel it is risky to invest in stocks market \\
& I want to invest in share market in the next time \\
& I am likely to invest in share market in the next time \\
\hline
\end{tabular}

Table 3. Variable description

\begin{tabular}{ll}
\hline \multirow{2}{*}{ Investment Performance } & The return rate of my recent stock investment meets my expectation. \\
My earned rate of return is equal to or higher than the average return rate of the market. \\
I am satisfied with my investment decisions in the last year (including selling, buying, \\
choosing stocks, and deciding the stock volumes).
\end{tabular}

\section{Research Model}

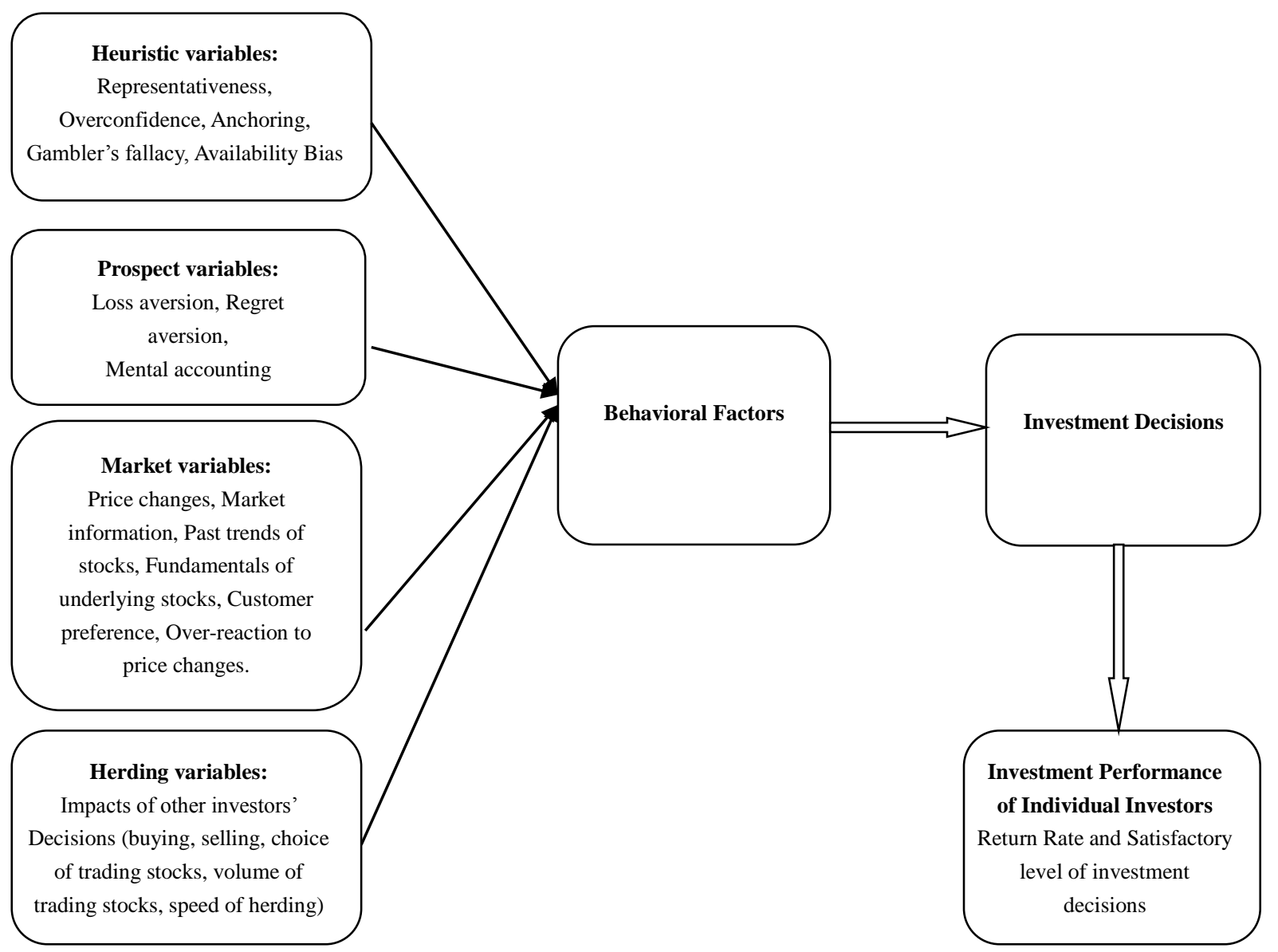

Figure 1. Research model

\subsection{Hypotheses}

H1: The behavioral variables that influence the investment decisions of individuals at the National Stock Exchange are grouped in four factors as the reviewed theories: Heuristics, Prospect, Market, and Herding.

H2: The behavioral factors have influence on the investment decisions of individual investors at the National Stock Exchange at high levels.

H3: The investment decisions of individual investors have positive influence on the investment performance at the National Stock Exchange.

\subsection{Data Analysis Method}

The data collected was processed and analyzed by SPSS. The statistical techniques used for the data to reach the objectives of the research include descriptive statistics, factor analysis and multiple regression analysis. 
A total of 500 questionnaires were distributed for data collection, but 361 were completed and processed. Exploratory factor analysis (EFA) and multiple regression tests were used to identify the factors of investor behavior and to know the impact of behavioral factors in investment decisions and impact of investment decisions on investment performance.

\subsection{Multicollinearity}

In order to detect multicollinearity problem among independent variable multicollinearity test was applied.

\section{Analysis and Interpretation}

3.1 Factor Analysis of Behavioral Variables Influencing the Individual Investment Decisions and Investment Performance

The exploratory factor analysis (EFA) is used for the variables of behavior and return on investment (Q1 to Q18) to identify the factors to which these variables belong to the requirements of the factor analysis to reduce the variables. After a few rounds to eliminate the insufficient variables, the analysis shows that the remaining variables are grouped into six factors (five factors of behavioral variables and an investment performance factor), in the $\mathrm{KMO}=0.649(\mathrm{sig}=0.000), \%$ of the total variance explained $=69.544 \%$, and all factor loads are more than 0.5 . These indices show that the factor analysis for these variables is quite adequate and accepted. The result is presented in the Table 4.

Table 4. KMO and Bartlett's test

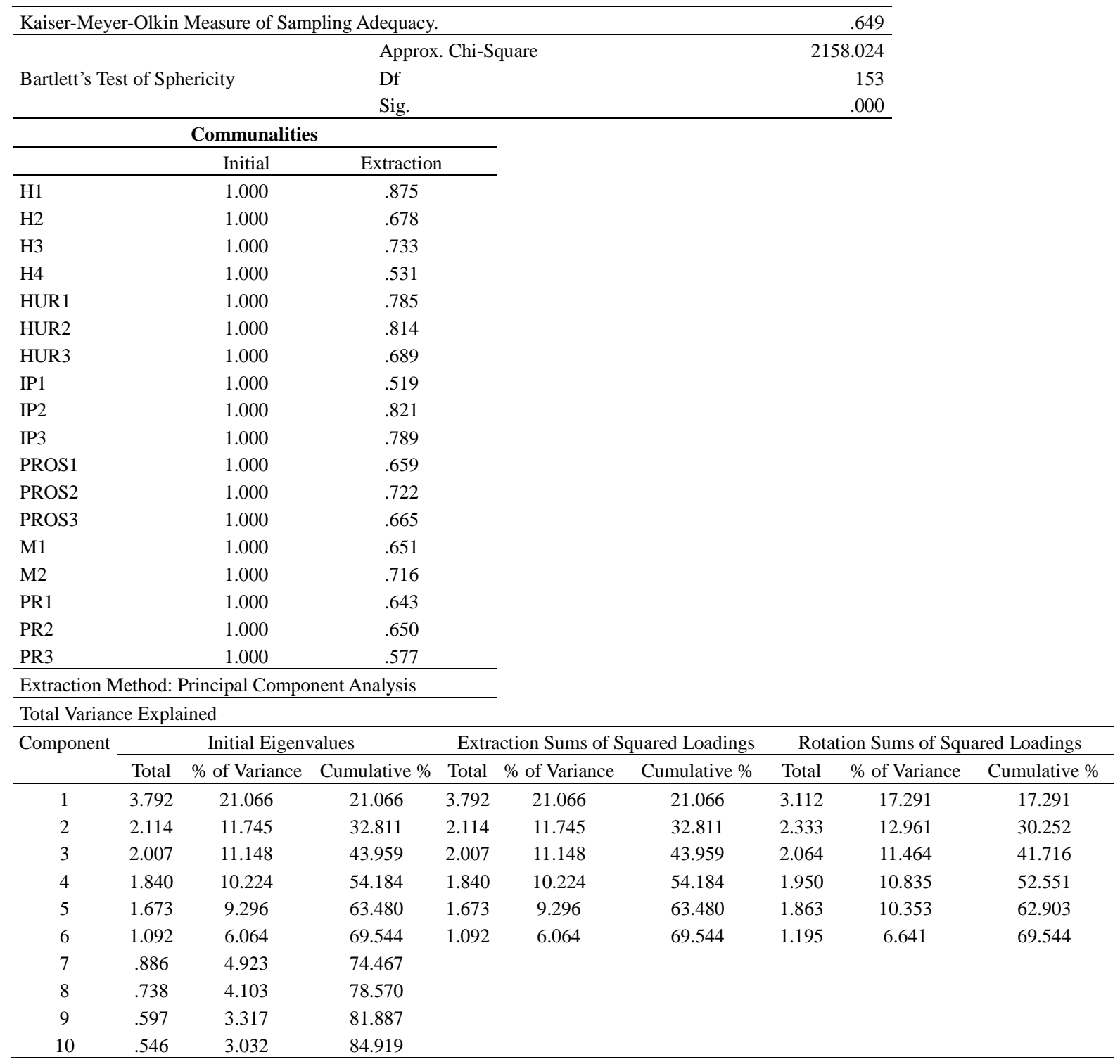




\begin{tabular}{cccc}
\hline 11 & .536 & 2.980 & 87.900 \\
12 & .477 & 2.652 & 90.551 \\
13 & .452 & 2.509 & 93.060 \\
14 & .335 & 1.860 & 94.920 \\
15 & .313 & 1.737 & 96.657 \\
16 & .262 & 1.455 & 98.112 \\
17 & .191 & 1.060 & 99.172 \\
18 & .149 & .828 & 100.000 \\
Extraction Method: Principal Component Analysis.
\end{tabular}

\subsubsection{Factor Analysis}

\section{INFERENCE:}

KMO and Bartlett's test Table 4. KMO statistics is greater than 0.05, indicating that factor analysis can be used for given data.

In this KMO AND Bartlett's test, sampling adequacy is .649 which is above then .5 , which means sampling adequacy is accurate.

$>$ Bartlett's test value is .000 which is significant value.

\section{INTEREPRETATION:}

From the Table 4, it is inferred that the given value is more than 1 for four factors and the cumulative value is accumulated to the extent of 69.544 the variable is well explained by the six factors.

Table 5. Rotated Component Matrix ${ }^{\mathrm{a}}$

\begin{tabular}{|c|c|c|c|c|c|c|c|}
\hline \multirow[t]{2}{*}{ Factors } & \multirow[t]{2}{*}{ Variables } & \multicolumn{6}{|c|}{ Factor Loading } \\
\hline & & $\mathrm{F} 1$ & $\mathrm{~F} 2$ & $\mathrm{~F} 3$ & $\mathrm{~F} 4$ & F5 & F6 \\
\hline \multirow[t]{4}{*}{ Herding } & $\begin{array}{l}\text { Q.1 My Investment decision of purchasing shares is influenced by decisions of } \\
\text { other investors. }\end{array}$ & .730 & & & & & \\
\hline & $\begin{array}{l}\text { Q.2 My Decision of purchase of volume of stock is affected by other investors } \\
\text { purchase. }\end{array}$ & .720 & & & & & \\
\hline & $\begin{array}{l}\text { Q.3 Other investors' decisions of buying and selling stocks have impact on my } \\
\text { investment decisions }\end{array}$ & .670 & & & & & \\
\hline & $\begin{array}{l}\text { Q.4 I usually react quickly to the changes of other investors' decisions and follow } \\
\text { their reactions to the stock market }\end{array}$ & 646 & & & & & \\
\hline \multirow[t]{3}{*}{ Heuristics } & $\begin{array}{l}\text { Q.5 I believe that my skills and knowledge of stock market can help me to } \\
\text { outperform the market. }\end{array}$ & & .770 & & & & \\
\hline & Q.6 I rely on my previous experiences in the market for my next investment. & & .735 & & & & \\
\hline & $\begin{array}{l}\text { Q.7 I try to estimate the changes in stock prices in the future based on the current } \\
\text { stock prices. }\end{array}$ & & .697 & & & & \\
\hline Investment & Q.16 I feel it is risky to invest in stocks market & & & .807 & & & \\
\hline \multirow{2}{*}{ Decision } & Q.17 I want to invest in share market in the next time & & & .756 & & & \\
\hline & Q.18 I am likely to invest in share market in the next time & & & .421 & & & \\
\hline Investment & Q.8 The return rate of my recent stock investment meets my expectation. & & & & .676 & & \\
\hline \multirow[t]{2}{*}{ Performance } & $\begin{array}{l}\text { Q.9 My earned rate of return is equal to or higher than the average return rate of } \\
\text { the market. }\end{array}$ & & & & .628 & & \\
\hline & $\begin{array}{l}\text { Q.10 I am satisfied with my investment decisions in the last year (including } \\
\text { selling, buying, choosing stocks, and deciding the stock volumes). }\end{array}$ & & & & .496 & & \\
\hline \multirow[t]{3}{*}{ Prospect } & Q.11 After a prior gain, I have become more risk seeking than usual. & & & & & .822 & \\
\hline & Q.12 After a prior loss, I have become more risk averse. & & & & & .557 & \\
\hline & $\begin{array}{l}\text { Q.13 You avoid selling shares that have decreased in value and readily sell shares } \\
\text { that have increased in value. }\end{array}$ & & & & & .413 & \\
\hline \multirow[t]{5}{*}{ Market } & Q.14 I react to price change of stocks in market & & & & & & .693 \\
\hline & $\begin{array}{l}\text { Q.15 I analyze the companies' customer preference before investing in their } \\
\text { stocks }\end{array}$ & & & & & & .383 \\
\hline & Extraction Method: Principal Component Analysis. & & & & & & \\
\hline & Rotation Method: Varimax with Kaiser Normalization. & & & & & & \\
\hline & a. Rotation converged in 9 iterations. & & & & & & \\
\hline
\end{tabular}




\section{INTERPRETATION}

As shown in the table 5 the variables herding, heuristics, investment performance, prospect, and market are grouped into related factors. Some of the factor loadings of the variables have been removed from the analysis since their factor loadings are less than 0.5. The result illustrates those behavioral variables that are the investment decisions of individuals in the NSE are grouped into four factors such as the revised theories: Herding, Heuristics, Prospect and Market, and hence supporting H1. As such, there are four behavioral factors that influence investment decisions of individual investors in the NSE. Factor in the herding, the four original questionnaire variables remain after factor analysis.

\subsection{Reliability}

Table 6. Reliability table

\begin{tabular}{lc}
\hline Variables & Cronbach' Alpha \\
\hline Herding & 0.766 \\
Heuristics & 0.748 \\
Prospect & 0.694 \\
Market & 0.610 \\
Investment Decisions & 0.651 \\
Investment Performance & 0.619 \\
Overall Reliability & 0.709 \\
\hline
\end{tabular}

The internal consistency of the items used to measure each factor was calculated using the Cronbach's alpha, which is the procedure of choice to examine the internal consistency of the items using the Likert-type scale (Walsh \& Betz, 1995). Cronbach's alpha for each factor: factor 1 (Herding), factor 2 (Heuristics), factor 3 (Investment performance), factor 4 (Prospect), factor 5 (Market), factor 6 (Investment decision) was 0.766, 0.748, $0.619, .694,610$ and 0.651 , respectively. As the marginal acceptable reliability should be higher than 0.60 (Gliner\& Morgan, 2000), all the measures in this study are above 0.60 , demonstrating reliability. Therefore, the results of the reliability analysis confirmed that consistency on each of the factors is at an acceptable level.

Table 7. Overall reliability

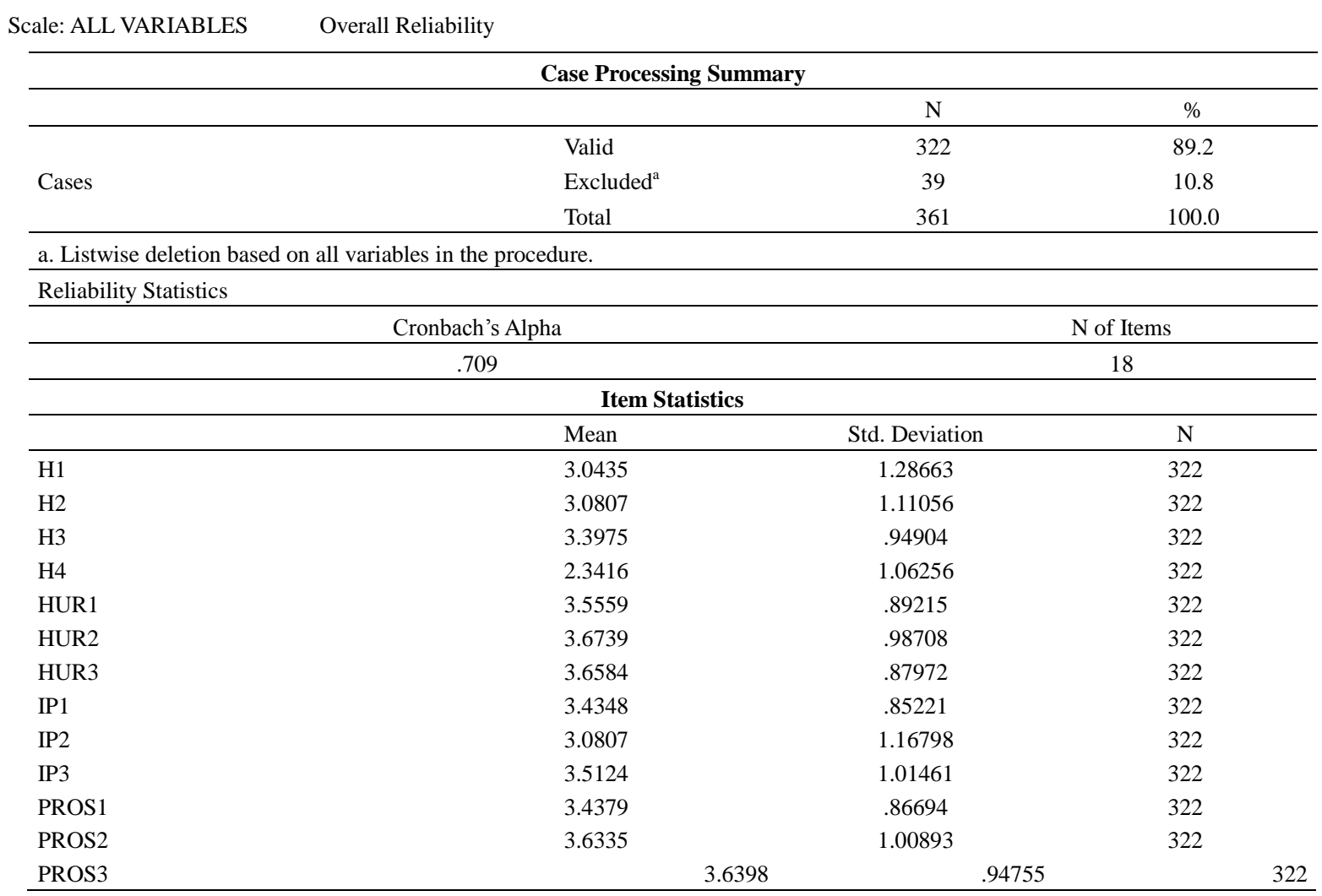




\begin{tabular}{llrr}
\hline M1 & 3.5342 & .95396 & 322 \\
M2 & 3.8199 & .84932 & 322 \\
PR1 & 3.3230 & .93130 & 322 \\
PR2 & 3.5404 & .96347 & 322 \\
PR3 & 3.2174 & 1.13947 & 322 \\
\hline
\end{tabular}

Table 8. Regression

\begin{tabular}{|c|c|c|c|c|c|c|c|c|c|}
\hline \multicolumn{10}{|c|}{ Variables Entered/Removed $^{\mathrm{a}}$} \\
\hline \multicolumn{2}{|l|}{ Model } & \multicolumn{3}{|c|}{ Variables Entered } & \multicolumn{3}{|c|}{ Variables Removed } & \multicolumn{2}{|c|}{ Method } \\
\hline 1 & \multicolumn{4}{|c|}{ Herding, Heuristics, Prospect Market } & & & & \multicolumn{2}{|c|}{ Enter } \\
\hline \multicolumn{10}{|c|}{ a. Dependent Variable: investment decisions } \\
\hline \multicolumn{10}{|c|}{ b. All requested variables entered. } \\
\hline \multicolumn{10}{|c|}{ Model Summary } \\
\hline \multicolumn{2}{|c|}{ Model } & \multicolumn{2}{|c|}{$\mathrm{R}$} & R Square & \multicolumn{3}{|c|}{ Adjusted R Square } & \multicolumn{2}{|c|}{ Std. Error of the Estimate } \\
\hline \multicolumn{2}{|c|}{1} & \multicolumn{2}{|l|}{$.571^{\mathrm{a}}$} & .326 & \multicolumn{3}{|c|}{.318} & \multicolumn{2}{|c|}{.53525} \\
\hline \multicolumn{10}{|c|}{ a. Predictors: (Constant), Herding, Heuristics, Prospect and Market } \\
\hline \multicolumn{10}{|c|}{ ANOVAa } \\
\hline \multicolumn{2}{|c|}{ Model } & & Sum of Squares & Df & \multicolumn{2}{|c|}{ Mean Square } & $\mathrm{F}$ & \multicolumn{2}{|c|}{ Sig. } \\
\hline & \multicolumn{2}{|c|}{ Regression } & 43.987 & 4 & & .997 & 38.38 & 384 & $00^{\mathrm{b}}$ \\
\hline 1 & Resic & & 90.817 & 317 & & 286 & & & \\
\hline & Total & & 134.803 & 321 & & & & & \\
\hline a. Depe & dent Variable: & investment deci & sions & & & & & & \\
\hline b. Pred & tors: (Constan & , Herding, Heu & Iristics, Prospect and & Market & & & & & \\
\hline & & & Coefficient & & & & & & \\
\hline Model & & Unstandardi & zed Coefficients & Standardized Coeff & ents & $\mathrm{t}$ & Sig. & Collinearity S & tatistics \\
\hline & & $\mathrm{B}$ & Std. Error & Beta & & & & Tolerance & VIF \\
\hline & (Constant) & 1.424 & .239 & & & 5.950 & .000 & & \\
\hline & Herding & .276 & .040 & & .343 & 6.933 & .000 & .932 & 1.073 \\
\hline 1 & Heuristics, & .127 & .047 & & .137 & 2.680 & .008 & .923 & 1.084 \\
\hline & Prospect & .260 & .046 & & .280 & 5.614 & .000 & .932 & 1.073 \\
\hline & Market & .073 & .033 & & .102 & 2.201 & .028 & .929 & 1.076 \\
\hline a. Depe & dent Variable: & nvestment deci & sions & & & & & & \\
\hline & & & Coll & linearityDiagnostics & & & & & \\
\hline Model & Dimension & Eigenvalue & Condition Index & & & riance $\operatorname{Prc}$ & portions & & \\
\hline & & & & (Constant) & & Herding $\mathrm{F}$ & euristics & Prospects & Market \\
\hline & 1 & 4.891 & 1.000 & & .00 & .00 & .00 & .00 & .00 \\
\hline & 2 & .038 & 11.350 & & .00 & .60 & .00 & .06 & .39 \\
\hline 1 & 3 & .034 & 12.060 & & .00 & .03 & .01 & .77 & .35 \\
\hline & 4 & .026 & 13.652 & & .02 & .29 & .59 & .06 & .19 \\
\hline & 5 & .011 & 20.809 & & .98 & .07 & .39 & .11 & .07 \\
\hline
\end{tabular}

\subsection{Multicollinearity}

To detect the multicollinear problem, the independent variable multicollinearity test was applied Table 8 . The values of the Variation Inflation Factor (VIF) for all variables are less than ten, indicating that the multicollinearity problem is minimized and that the variables for regression analysis can be used (Chatterjee et al., 2000; Kleinbaum et al., 1988).

\subsection{Regression}

H2: The behavioral factors have influence on the investment decisions of individual investors at the National Stock Exchange at high levels.

\section{Interpretation}

The hypothesis is accepted because ( $\mathrm{p}<0.05,0.000$ ) in this study is behavioral factors (Herding, Heuristics, Prospect and Market) that influence the investment decisions of individual investors in the National Stock 
Exchange at high levels (Table 8).

H3: The investment decisions of individual investors have positive influence on the investment performance at the National Stock Exchange.

Table 9. Regression

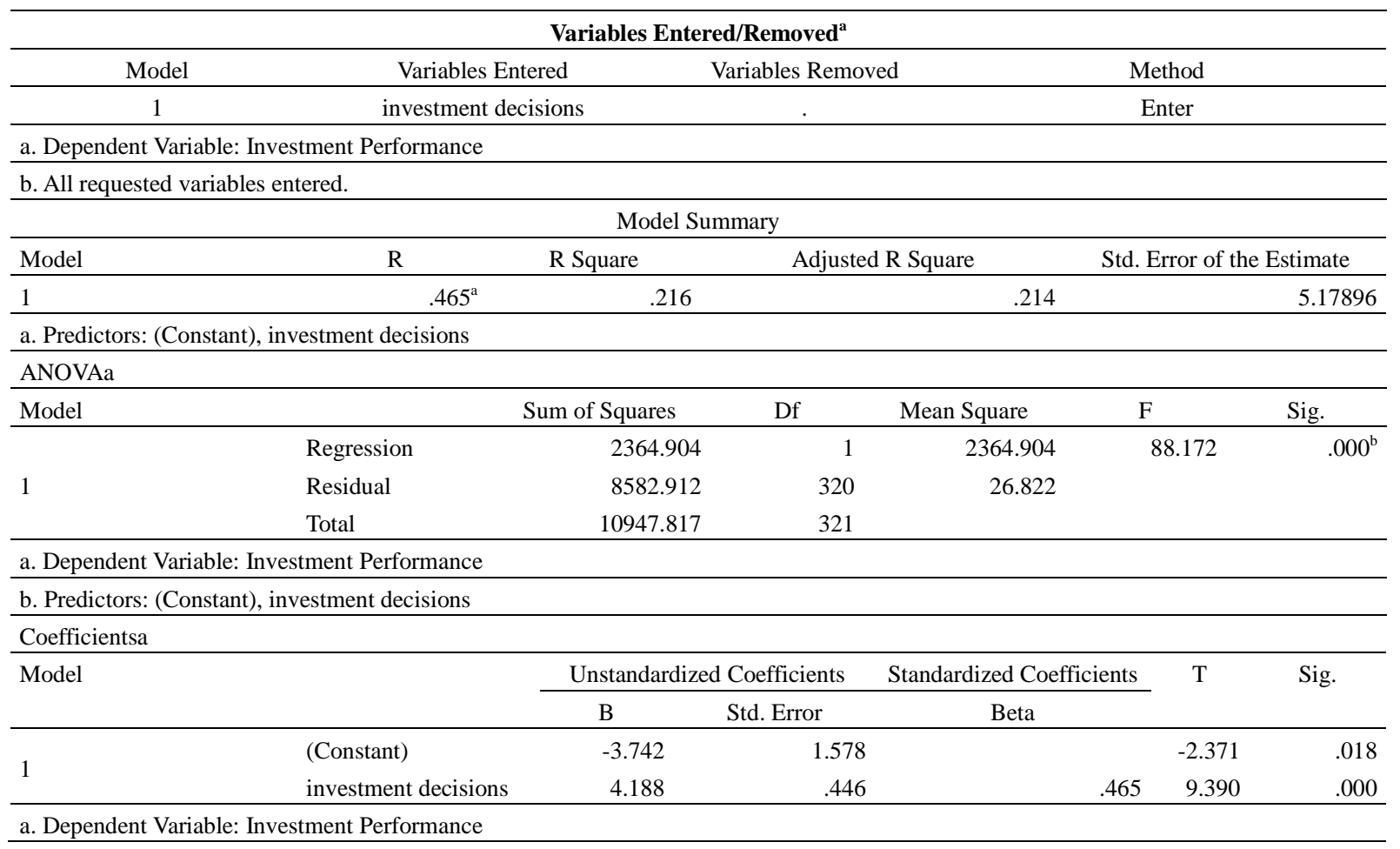

\section{Interpretation}

The hypothesis is accepted because $(\mathrm{p}<0.05,0.000)$ indicating that investment decisions by individual investors have a positive impact on the performance of the investment in the National Stock Exchange (Table 9).

\subsection{Summary of the Hypotheses Test}

Table 10. Summary of hypotheses

\begin{tabular}{cl}
\hline Sr. No. & \multicolumn{1}{c}{ Hypotheses } \\
\hline 1 & $\begin{array}{l}\text { H1: The behavioral variables that influence the investment decisions of individuals at the National Stock Exchange Accepted } \\
\text { are grouped in four factors as the reviewed theories: Heuristics, Prospect, Market, and Herding. }\end{array}$ \\
2 & $\begin{array}{l}\text { H2: The behavioral factors have influence on the investment decisions of individual investors at the National Stock Accepted } \\
\text { Exchange at high levels. }\end{array}$ \\
& $\begin{array}{l}\text { H3: The investment decisions of individual investors have positive influence on the investment performance at the Accepted } \\
\text { National Stock Exchange. }\end{array}$
\end{tabular}

\section{Findings of the Study}

The internal consistency of the elements used to measure each factor was calculated using the Cronbach's alpha, which is the procedure of choice to examine the internal consistency of the elements using the Likert-type scale (Walsh \& Betz, 1995). Cronbach's alpha for each factor: factor 1 (Herding), factor 2 (heuristics), factor 3 (investment performance), factor 4 (prospect), factor 5 (market) and factor 6 (investment decisions) were 0.766 , $0.748,0.610,0.694,0.610$ and 0.651 , and the overall reliability was 0.709 . As the marginal acceptable reliability should be higher than 0.60 (Gliner \& Morgan, 2000), all the measures in this study are above 0.60 , demonstrating reliability. Therefore, the results of the reliability analysis confirmed that consistency on each of the factors is at an acceptable level.

The finding of the analysis is that the four variables significantly affected the investment decision and the return on 
investment. All behavioral variables have a major impact on investors' decision-making, which has led to the acceptance of all hypotheses related to the impact of the behavioral factors in the decision-making of individual investors.

\section{Implications of the Study}

Capital markets are an essential part of the financial sectors of modern economies and even more of growing economies. Well-developed capital markets promote economic growth through increased savings and mobilization, access to external savings, the spread of financial risk and the facilitating role in converting savings into investments. The stock market decisions play an important role in determining market trends, which then influence the economy. In order to understand and provide an adequate explanation for investor decisions, it is important to investigate which behavior factors influence investor decisions in the Stock Exchange and how these factors influence their investment performance. In this sense, we have examined each of the behavioral factors.

\section{Conclusion}

Based on the analysis, it was found that there are four behavioral factors affecting the investment decisions of individual investors in the National Stock Exchange: Herding, Market, Prospect, Heuristic. The herding factor includes four behavioral variables: follows the decisions of other investors (buying and selling, choice of trading stocks, volume of stock; herding speed). The market factor consists of three variables: changes in prices, market information and past trends of the stocks, fundamentals of the underlying shares, customer preference, over-reaction to price changes. The prospect theory has three variables: loss aversion, regret aversion and mental accounting, that have significant impact on investment decision making: aversion to loss, regret aversion and mental accounting (two sub-variables). And that decision-making influences the return on investment of individual investors that include two factors, namely the rate of return and the satisfactory level of investment decisions.

While heuristic variables are grouped into five factors: representativeness, overconfidence-gamble's fallacy and anchoring and availability bias. The factor of over-dependence gamble's fallacy consists of two variables: overconfidence and gamble's fallacy while two variables: anchoring and ability bias belong to the factor of anchoring-ability bias.

The findings indicate that hypothesis $\mathrm{H} 1$ is supported. The four behavioral factors affect investment decisions by individual investors on the National Stock Exchange at high levels and investment decisions by individual investors have a positive impact on investment performance on the National Stock Exchange. The findings indicate that hypotheses $\mathrm{H} 2$ and $\mathrm{H} 3$ are also supported.

\section{References}

Central Bank of Sri Lanka.(2012). Annual Report. Colombo, Sri Lanka. Retrieved from http://www.cbsl.lk

Daniel, K. P. S. (1982). A progress report on the training of probability assessors in Judgment Under Uncertainty: Heuristics and Biases. Cambridge University Press.

DeBondt, W. F. M., \& Thaler, R. H. (1995). Financial Decision-Making in Markets and Firms: A Behavioral Perspective. Handbooks in Operations Research and Management Science, 9(13), 385-410. https://doi.org/10.1016/S0927-0507(05)80057-X

Filbeck, G., Hatfield, P., \& Horvath, P. (2005). Risk aversion and personality type. Journal of Behavioral Finance, 6(4), 170-180. https://doi.org/10.1207/s15427579jpfm0604_1

Fisher, C. (2010). Researching and writing a dissertation, an essential guide for business students (3rd ed.). Pearson Eduction Limited.

Fromlet, H. (2001). Behavioral finance-theory and practical application: Systematic analysis of departures from the homo oeconomicus paradigm are essential for realistic financial research and analysis. Business Economics, 63-69.

George, D., \& Mallery, P. (2003). SPSS for Windows step by step: A simple guide and reference. 11.0 update (4th ed.). Boston: Allyn \& Bacon.

Gliner, J. A., \& Morgan, G. A. (2000). Research methods in applied settings: An integrated approach to design \& analysis. Morwah, NJ: Lawrence Erlbaum. https://doi.org/10.4324/9781410605337

Huang, N. B. (2001). Mental Accounting, Loss Aversion, and Individual Stock Returns. The Journal of Finance, 1247-1292. https://doi.org/10.1111/0022-1082.00367

Hvide, H. K. (2002). Pragmatic beliefs and overconfidence. Journal of Economic Behavior \& Organization, 
48(1), 15-28.

Kahneman, D., \& Tversky, A. (1979). Prospect theory: an analysis of decision-making under risk. Econometrica, 47(2), 263-291. https://doi.org/10.2307/1914185

Kallinterakis, V., Munir, N., \& Markovic, M. R. (2010). Herd Behavior, Illiquidity, and Extreme Market States: Evidence from Banja Luka. Journal of Emerging Market Finance, 9(3), 305-324. https://doi.org/10.1177/097265271000900303

Kim, K. A., \& Nofsinger, J. R. (2008). Behavioral finance in Asia. Pacific-Basin Finance Journal, 16(1), 1-7. https://doi.org/10.1016/j.pacfin.2007.04.001

Nofsinger, J. R. (2001). Investment madness: How psychology affects your investing - and what to do about it. USA: Pearson Education.

Ritter, J. R. (2003). Behavioral Finance. Pacific-Basin Finance Journal, 11(4), 429-437. https://doi.org/10.1016/S0927-538X(03)00048-9

Rockenbach, B. (2004). The behavioural relevance of mental accounting for the pricing of financial options. Journal of Economic Behavior and Organization, 53(4), 513-527. https://doi.org/10.1016/S0167-2681(03)00097-0

Sim, B. S., \& Laurie, R. W. (1995). The Academy of Management Journal, 38(6), 1573-1592. https://doi.org/10.5465/256844

Slovic, P. (2000). Rejoinder: The perils of Viscusi's analyses of smoking risk perceptions. Journal of Behavioral Decision Making, 13(2), 273-276.

Tan, L., Chiang, T. C., Mason, J. R., \& Nelling, E. (2008).Herding behavior in Chinese stock markets: An examination of A and B shares. Pacific-Basin Finance Journal, 16(1), 61-77. https://doi.org/10.1016/j.pacfin.2007.04.004

Tversky, A., \& Derek, J. K. (1994). Support Theory: A Nonextensional Representation of Subjective Probability. Psychological Review, 101, 547-567.

Walsh, W. B., \& Betz, N. E. (1995). Tests and assessment (3rd ed.). Englewood Cliffs, N.J.: Prentice Hall.

Waweru, N., M., Munyoki, E., \& Uliana, E. (2008). The effects of behavioral factors in investment decision-making: A survey of institutional investors operating at the Nairobi Stock Exchange. International Journal of Business and Emerging Markets, 1(1), 24-41. https://doi.org/10.1504/IJBEM.2008.019243

Weber, E. U. (2004). Perception matters: Psychophysics for economists. The Psychology of Economic Decisions, 2, 163-176.

Weber, E. U., Blais, A. R., \& Betz, N. E. (2002). A domain-specific risk-attitude scale: Measuring risk perceptions and risk behaviors. Journal of Behavioral Decision Making, 15(4), 263-290.

\section{Copyrights}

Copyright for this article is retained by the author(s), with first publication rights granted to the journal.

This is an open-access article distributed under the terms and conditions of the Creative Commons Attribution license (http://creativecommons.org/licenses/by/4.0/). 